\title{
Antropología para el pueblo La portada de nuestro primer número
}

Norling Sabel Solís Narváez

U $\mathrm{n}$ árbol frondoso, lleno de vigor, florecido bajo un cielo tropical, protagoniza el espacio de la portada de nuestro primer número: hemos logrado culminar el sueño de tener la primera Revista virtual nicaragüense de Antropología.

No es para menos nuestra alegría cuando memoramos para quién se escribe o gracias a quién se hace antropología: el pueblo. Ese pueblo que en los versos de Rubén Darío es "vibrante, fuerte, apasionado, altivo" y "tiene la conciencia de ser vivo...".

Estamos de fiesta por distintas razones: festejamos el centenario del paso a la inmortalidad del príncipe de las letras castellanas, Rubén Darío, festejamos el lema de la UNAN-Managua, "Año de la Madre Tierra", estamos festejando la dignidad del trabajador y trabajadora nicaragüense, estamos festejando el restablecimiento de los derechos de la niñez, la gracia de estar en un país libre, construyendo la Nicaragua de todas y todos en esta segunda etapa de la Revolución. Estamos festejando la gratitud de sacar el Primer Número de la Revista Raíces.

Nuestra portada muestra las raíces que mantienen vivo el árbol de los saberes populares y ancestrales, el árbol de los sueños alcanzados, de las luchas ganadas, el árbol de nuestra identidad multicultural plurilingüe.

Las raíces de este árbol están sustentadas en mujeres, hombres, niñas y niños nicaragüenses, que aportan con sus vidas y experiencias al desarrollo de nuestro país, esa mujer indígena valiente que día a día se levanta con el deseo de forjar como sus ancestros le han enseñado y que ella transmite a sus generaciones.

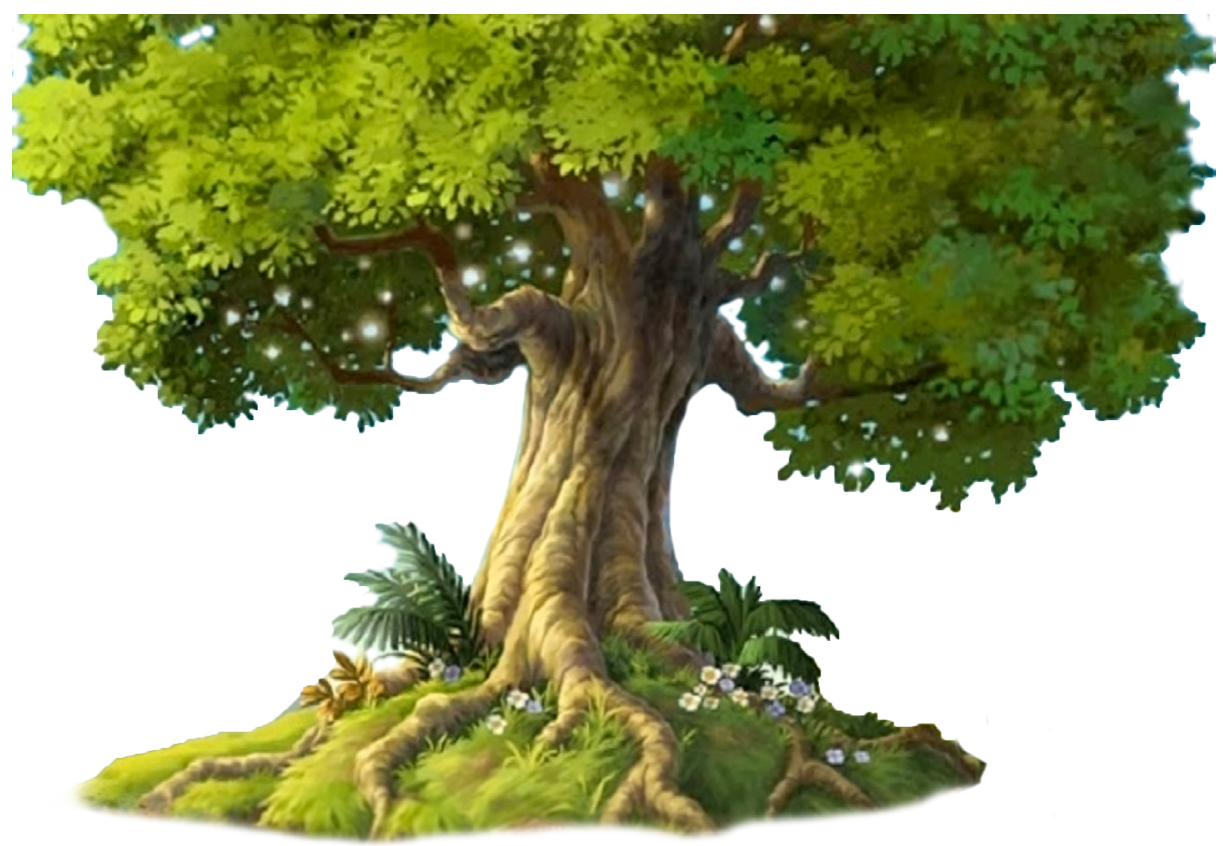


Ese hombre obrero o campesino procurando el alimento para la familia. Las raíces son fuentes de vida, por eso son las plantas el mejor reflejo de la armonía entre la tierra y el cielo, un árbol enraizado con él y la nicaragüense, que en sus escondidas memorias resguardan el tesoro de la sabiduría de esos ancianos $\mathrm{y}$ ancianas. Por supuesto en nuestras raíces está también la alegría de los juegos de la niñez nicaragüense, el presente y futuro de este país, por la cual se lucha incansablemente.

Nuestra cultura tiene la esencia sutil de los protagonistas de esta portada, hombres, mujeres, niños y niñas descendientes de los primeros pobladores de la Nicaragua precolombina. Una civilización que se vislumbra a través de sus expresiones artísticas, los petroglifos milenarios, pero también persiste en los nahualismos que caracterizan nuestra habla, en las recetas tradicionales, en las piezas artesanales, en los bailes y en las celebraciones religiosas. Así como en un sinnúmero de prácticas cotidianas y costumbres, que tanto en el campo como en la ciudad nos hablan de una Nicaragua profunda mucho más indígena de lo que imaginamos.

Queremos expresar al son de la música folclórica de nuestra Nicaragua, el orgullo de nuestras raíces ancestrales, que se encuentran todavía vivas bajo la piel mestiza.
Nos encontramos en una coyuntura especial: Nicaragua está viviendo una de sus mejores etapas y tenemos que ser protagonistas de ese andar. Nuestro andar será reflejado en este trabajo conjunto, dando voz a aquellos que en silencio logran construir la patria de Sandino y Darío. Como antropólogas y antropólogos comprometidos estamos conscientes que es vital documentar las memorias y experiencias de nuestro pueblo: será una tarea ardua pero necesaria.

Por tal razón reafirmamos nuestro compromiso de ejercer antropología y acompañar los procesos de desarrollo comunitario y revitalización de nuestra identidad a través de la escritura. Escribiremos no sólo para el científico social, ni para el ilustrado, sino para ese público encontrado en el mosaico nicaragüense. Y si documentar lo no documentado de la realidad social es la tarea del antropólogo, presentar ese resultado a quienes le permitieron lograrlo es una obligación moral. Porque el antropólogo debe ser para el pueblo, comunicador de sus ideas, como la revolución en la voz popular.

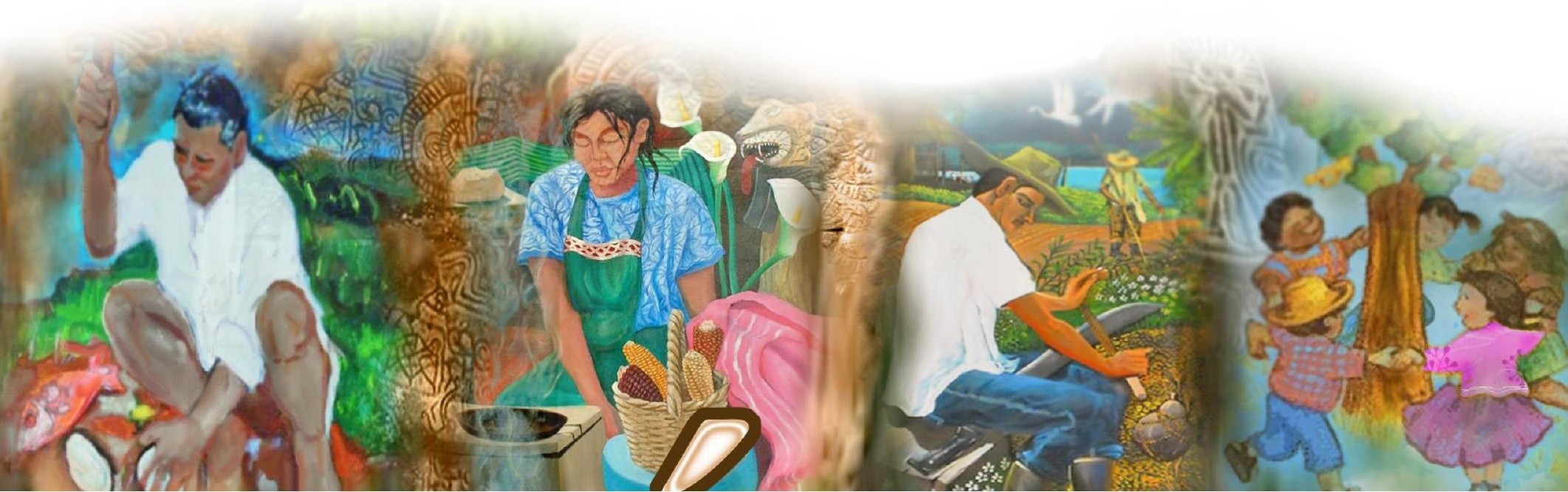

